\title{
Enhancing Cultural Heritage Tourism Experience with Augmented Reality Technology in Bali
}

\author{
Gde Indra Bhaskara and Dian Pramita Sugiarti \\ Faculty of Tourism Udayana University \\ Corresponding author: gbhaskara@unud.ac.id
}

\begin{abstract}
ARTICLE INFO
Received

11 February 2019

Accepted

04 March 2019

Available online

18 March 2019
\end{abstract}

Cultural heritage tourism industry is generally required to continuously be creative in finding new strategies for attracting and engaging tourists actively in enjoying this type of tourism. However, cultural heritage managers generally face challenges in marketing and competitiveness. One of the ways to gain competitive advantage is the implementation of the Augmented Reality technology. This study was conducted in order to recreate an interpretation of tourist attractions with the use of Augmented Reality in Bali with the aim of enhancing cultural heritage tourists experience. The methodology used are documentation, interview, usability study and observation. Researches on usability involves users in testing a prototype. The prototype here is an augmented reality app that present the condition of three tourist attractions in Bali (Kuta, Sanur and Uluwatu), back then to 19701980s, to the times before Mass Tourism became a threat like nowadays. The usability study and observation method are widely used to understand how people work with electronic devices such as mobile phones and tablets in recent days. The expected results in this study are to produce an app that is useful to enhance the experience of tourists in Bali and at the end it is expected to create a better appreciation to the culture, history of Bali and its tourism.

Keywords: Augmented Reality, Cultural, Heritage, Tourism, Tourist, Experience, Bali

\section{INTRODUCTION}

\section{Background}

Augmented Reality, which is further shortened to AR, is one of the most innovative and promising technologies (Attila and Edit, 2012; Jung and Han, 2014), and that AR is believed to encourage added value benefits and ultimate experience based entirely on recent technology (Neuhofer et al. 2013). Augmented Reality (AR), a visualization technique that superimposes virtual information over real world views in real three-dimensional locations (Kounavis et al. 2012), is a popular method for enhancing a user's cognitive abilities to see 
the environment in real time (Azuma et al. 2001). AR provides an opportunity to provide value for benefits and quality of travel experience. According to Yovcheva et al (2013) utilizing AR will maximize the experience and satisfaction of tourists on the assumption that tourists will fully accept the use of this AR. Han et al. (2013) asserted that the use of the Augmented Reality is still a new issue in the world of tourism because this technology has not been refined. In addition, empirical studies of the augmented reality in the tourism sector are rarely found, including why people use the augmented reality or the effect of its use in tourist destinations. There is little research on the relationship between augmented reality and tourists in tourist destinations, even though the tourist-technology relationship has been studied in many contexts both theoretically and practically (Chung et.al., 2015). Integrating the Augmented Reality that is successful in the world of tourism, especially cultural heritage tourism will make an important contribution. The important contribution here is to offer value added for tourists visiting Bali, thus they will not solely gain entertainment, however they will also obtain education about the history of tourist areas in Bali.

\section{Research Objectives}

This study aims to help improve the experience of traveling in Bali, especially cultural heritage tourism. From this study, it is also expected that tourists and apps users will be aware of the dangers of mass tourism and tourism exploitation in Bali. This awareness will be created after tourists use this application and obtain a direct comparison of the atmosphere of tourist areas in Bali in the past directly on the scene compared to the recent situation. In addition to entertainment that can be experienced through the nostalgia of tourist areas in the past, this application can also educate tourists. The expected results of this study are the creation of a mobile application that can be patented and downloaded on Android and IOS phones. In the end, the creation of the Augmented Reality application will not merely enhance the tourist experience of tourists in Bali, however also to introduce Balinese history and culture to the world indirectly.

\section{LITERATURE REVIEW}

\section{Augmented Reality}

The latest developments in mobile and wireless devices have enabled the growth of applications called Augmented Reality on mobile devices (Azuma et al., 
2001). Augmented Reality is a visualization technique that synthesizes a variety of multimedia information both two and three dimensions in the threedimensional real world (Kounavis et. Al., 2012). Milgram et al. (1994) states that the evolution and development of the Reality of Augmented Reality is closely related to Virtual Reality or what is known as Virtual Reality (VR). However, there is a difference between the two in which Virtual Reality is fully artificial (Figure 1), in Augmented Reality, a "virtual world layering the real world with additional information" (Feiner et al. 1997). The results can be placed along the RealityVirtuality continuum (Figure 1).
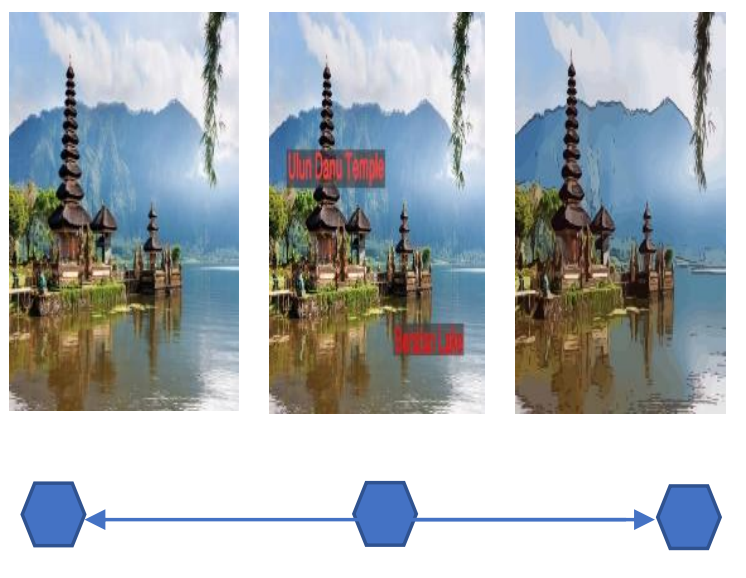

Real

World contrary, if real objects are augmented to the virtual environment, the result is Augmented Virtuality, (AV). In contrast to Virtual Reality and Augmented Virtuality, Augmented Reality has the potential to enhance reality perception in real-time by superimposing information into a particular place, because of the system of Augmented Reality (Azuma et al., 2001): combining real and virtual objects in a real environment, operated interactively and in real time (now). This widely accepted definition emphasizes the fact that a system can be called an Augmented Reality if this system provides information that is in harmony with the user's environment.

Augmented Reality requires determining the direction and height of the mobile phone when used by the user. The most important thing to be considered is the position of the mobile phone must be in accordance with the object to be projected. Langlotz et al. 2014 refers to the process as registration and alignment (see figure 2).

Figure 1: The Reality-Virtuality Continuum

Source: Adaptation from Milgram et.al. (1994)

When virtual information is augmented to the real world, the result is Augmented Reality, whereas on the 


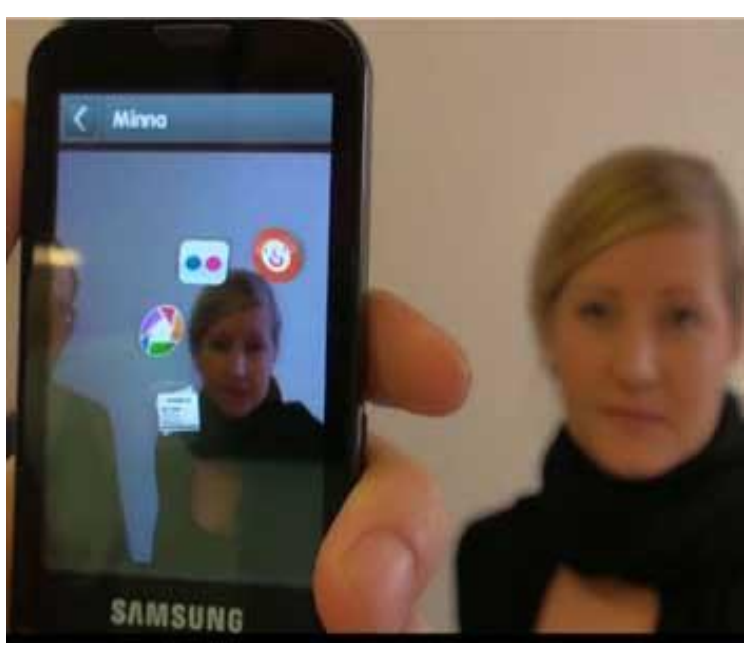

Figure 2: Tracking and Registration Process

Source:http://www.yantramstudio.com/aug mented-reality.html

After the process is carried out, the Augmented Reality system will ensure that virtual objects attached to the real world look aligned, this process is called tracking. This process is usually carried out by the registration component of Augmented Reality.

Henrysson and Ollila, 2004 state that in general, approaches to system and tracking can be divided into two categories: marker-based and marker-less. Augmented Reality based on tagging tracking requires a physical marker (such as a QR code). Virtual content is then overlaid on this marker (Möhring et al., 2004) (see figure 3). Although it is very good for indoor use, this marking is not feasible to use outdoors, because: (1) it takes time to make a lot of markers in each room or the object that you want to add http://ojs.unud.ac.id/index.php/eot reality increases; (2) limited to the magnitude of marking 3 ) requires that markers be scaled and adjusted their distance to be recognized by the system (Henrysson and Ollila, 2004).

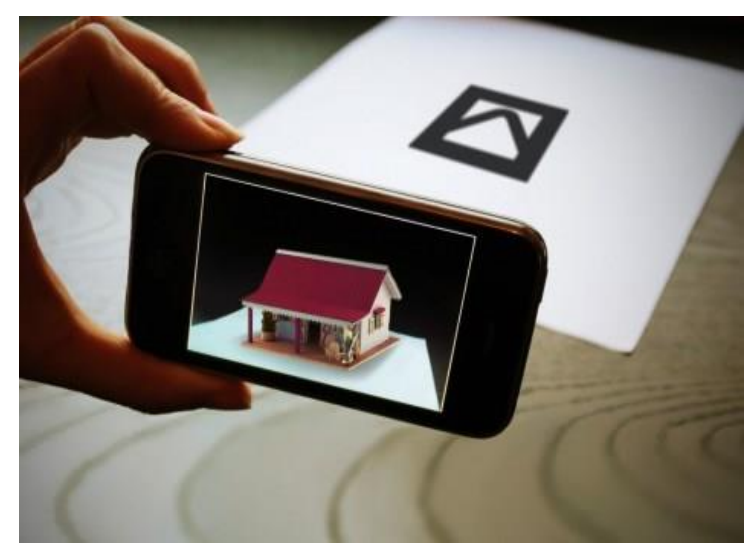

Figure 3: Augmented Reality with Marker Source : https://kcdev.id/

Marker-less tracking is considered more suitable for users in this case tourists, because in general they travel or roam in the environment they do not familiar with. There are three main things that are important and must exist in the use of Augmented Reality based on marker less, namely: the use of GPS, a computerised system and a combination of GPS and computerisation. Due to the absence of markers as media that contain information to run the Augmented Reality system, mobile phone that use system are augmented using GPS-based tracking. In essence, data from geomagnetic sensors (GPS, accelerometer, magnetometer) inside a mobile phone are combined with incoming data from the camera display to 
estimate orientation and the user's field of view (Madden, 2011). Based on these parameters, data is extracted from a central database that contains geo-tagged (location-based) and above that database, virtual information is embedded (see figure 4).

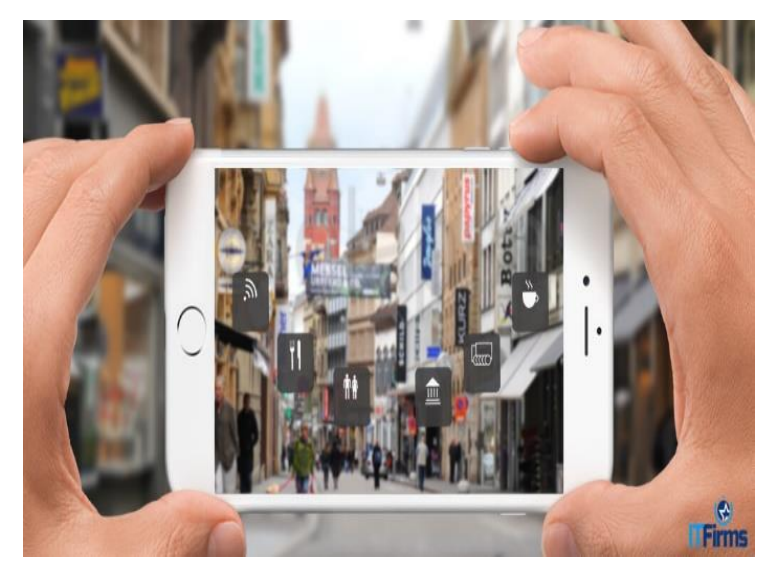

Figure 4: Marker less Augmented Reality Source : https://www.itfirms.co/top-5-

\section{Augmented Reality and Cultural Heritage}

The use of Augmented Reality to historical sites at this time is very common. Generally used to provide information about the history of a place, or reconstruct historical events. One example of the use of the Augmented Reality can be seen in the use of the method of tracking the Augmented Reality in buildings in the Gyeongbokgung palace in South Korea (Seo et al. 2010). In some rooms and courtyards, technology can bring the three-dimensional character / royal army in the past through a mobile phone or tablet screen (ibid). this certainly visiting the palace because they are able to witness first-hand the daily activities of the members of the palace in the 14th century (ibid).

The similar concept is found on historical sites in Venaria Palace, in northern Italy. In this palace, augmented reality is used to present paintings from this place in the past (Stricker et al. 2010). The media used is a portable laptop to present the past paintings. Visitors stand in front of the building in a row, and they can hear audio about the history of the place. Then, the 17th and 18th century paintings will appear when the portable laptop is directed to that particular building or point.

Similar research can be seen in Chang et al (2015), where researchers present a sense of place through this technology of augmented reality. Chang et al (2015) brings back the atmosphere of the past through this technology. The way they use is based on the principles of interpretation, among others: ensuring there is a bond and connectivity between visitors and historical places based on visitors' personal experience; increase visitor interest and ensure visitors understand the place visited; show the uniqueness of the place; invite visitors to be more active to explore historic sites and inspire and educate visitors through the e-ISSN: 2407-392X. p-ISSN: 2541-0857 
places visited. The media used and the style of delivery are through the technology of Augmented Reality which contains films, photos, songs, sounds related to ancient times (Chang et al. 2015).

Augmented Reality is also used to reconstruct buildings that have been damaged. This can be seen in a study by Girbacia et al. (2013) who restored virtually the damaged parts of Black Chruch, a church in Brasov, southeast of Transylvania, Romania. Parts were damaged by great fire are virtually displayed through augmented reality technology, thus visitors can view the church building as a whole (ibid). Augmented Reality Technology allows users to directly witness the stage of development and history of certain buildings and sites. The combination of additional information virtually and real scenes will enhance the feeling and experience of visitors at the scene. This technology can also present damaged artifacts by making them intact artefacts through mobile phone and tablet screens. Therefore, visitors can learn directly at the site.

\section{Augmented Reality in Indonesia}

In Indonesia, research and application of augmented reality have been carried out in many sectors. In the sector http://ojs.unud.ac.id/index.php/eot of education, augmented reality are used as a learning medium in Natural Sciences (Khotimah and Ardian 2017); interactive learning Basic Chemistry courses (Kamelia 2015); learning of the human blood circulation system (Tambayong et al 2016) ; human respiratory system (Novitasari and Arianto 2017; human digestive system (Saputro and Saputra 2015); educational character of early childhood (Senduk and Karouw 2016); numeracy recognition in Kindergarten (Abdullah 2014) letter and number recognition (Huda and Purwaningtias 2017); design of dinosaur encyclopaedia (Putra 2013) and solar and lunar eclipse study (Putra 2013) and easy ways to learn Islam's prayers ( Adrianti et al 2016).In the trade and marketing sector, augmented reality can be found in research on housing marketing and sales (Hidayat 2015; Gonydjaja and Pratomo 2016); Furniture product display (Muhammad 2014). In navigation and exploration, the augmented reality are implemented in showing the directions of the Stimata Campus (Pratama and Anwar 2013); Searching for Post Office in East Jakarta (Rachman 2013); searching for places of worship in Bekasi and Solo (Triyanti and Marleen 2014; Novitasari and Sulistyanto 2017) and geographic information systems for location of campuses in Bali (Atmojo and Paramartha 2014). In food and beverages, 
the use of Augmented Reality can be found in work by Setiawan and Haryanto (2012) which makes the detector application for traditional food expiration dates. In the same field, Fuad et al. (2017) utilise Augmented Reality as a medium for information on the nutritional content of Durian Fruit.

In Indonesia, Augmented Reality is used for the promotion historical buildings in Semarang City (Setiawan et al 2013) and the augmented reality-based quiz application is augmented to the museum (Yudiantika et al 2014). In the field of culture and cultural preservation, the augmented reality are found in the use of the introduction of Indonesian traditional houses (Prabowo et al 2015); South Sulawesi traditional house learning media (Johan and Syarif 2015); Central Java traditional musical instruments (Setyawan and Dzikri 2016) and adventure games about Rama and Rahwana (Lubis et al 2016). The use of Augmented Reality to the sectors associated with printing, can be found in Interactive brochures (Lengkey et al 2014; Meta 2015) and in the Radar Banyumas newspaper (Saputra et al 2015)

\section{Augmented Reality and Tourism}

Self-service technologies have been introduced as part of smart tourism by various tourism organisations. The http://ojs.unud.ac.id/index.php/eot latest and easily accessible self-service technologies in order to implement smart tourism is mobile technology. The active and dynamic nature of tourists have made mobile technology is naturally appropriate to accommodate the nature of tourists. Currently, mobile technology is used actively as a new form of service in the world of tourism (Gretzel et.al. 2015).

The use of Augmented in the tourism industry will be very practical, because Augmented Reality is used to help tourists to understand better the life and environment of the places where they are located. The main advantage is that tourists can view the information about interesting objects that are placed directly in a three-dimensional environment (Yovcheva et.al., 2013).

Various examples of the use of Augmented Reality can be found in tourism area in Indonesia. Examples of applications can be seen in catalogues of tourist attractions in Yogyakarta (Dewi and Waryanto 2016); website design based on Augmented Reality (Dharmawan and Lubis 2017) as well as tourism promotion activities in Lampung (Zaini and Endah 2015) and in Purbalingga (Tahyudin and Saputra 2017). In particular, in Bali, the use of Augmented Reality in tourism sector, still limited to the use of using markers (in general the printed media) and not using location based positioning 
(markerless). This use can be found in the introduction of the layout of the Ulun Danu Batur Temple (Darmawiguna et al 2014); Pura Luhur Batukaru (Anindya et al 2014) and Pura Lempuyang (Cahyani et al 2014). These three studies are still limited by how to design and more technical, rather than asking users' opinions about the use of this technology.

Interpretation of Cultural Heritage (Heritage Interpretation)

According to ICOMOS (2008), interpretation refers to the overall activities intended to increase public awareness and increase understanding of cultural heritage sites. Interpretation enriches the way we view life by engaging emotions, enriching experiences and deepening understanding of people, places, events and things from the past and present. The definition of ICOMOS and the Association for Heritage Interpretation refers to the interpretation concept presented by Tilden in his book Interpreting our heritage (1957). For more than 50 years, the principle principles contained in this book remain a reference for managers of museums and cultural heritage sites. Here are six basic principles from Tilden about Interpretation:
Table 1: Tilden's Six Basic Principles

\begin{tabular}{|c|c|}
\hline $\mathrm{Jo}$ & \\
\hline 1 & $\begin{array}{l}\text { Any interpretation that does not } \\
\text { somehow relate what is being } \\
\text { displayed or described to something } \\
\text { within the personality or experience } \\
\text { of the visitor will be sterile. }\end{array}$ \\
\hline 2 & $\begin{array}{l}\text { Information, as such, is not } \\
\text { Interpretation. Interpretation is } \\
\text { revelation based upon information. } \\
\text { But they are entirely different things. } \\
\text { However, all interpretation includes } \\
\text { information. }\end{array}$ \\
\hline 3 & $\begin{array}{l}\text { Interpretation is an art, which } \\
\text { combines many arts, whether the } \\
\text { materials presented are scientific, } \\
\text { historical or architectural. Any art is } \\
\text { in some degree teachable. }\end{array}$ \\
\hline 4 & $\begin{array}{l}\text { The chief aim of Interpretation is not } \\
\text { instruction, but provocation. }\end{array}$ \\
\hline 5 & $\begin{array}{l}\text { Interpretation should aim to present a } \\
\text { whole rather than a part, and must } \\
\text { address itself to the whole man rather } \\
\text { than any phase. }\end{array}$ \\
\hline 6 & $\begin{array}{l}\text { Interpretation addressed to children } \\
\text { (say up to the age of twelve) should } \\
\text { not be a dilution of the presentation } \\
\text { to adults, but should follow a } \\
\text { fundamentally different approach. To } \\
\text { be at its best it will require a separate } \\
\text { program }\end{array}$ \\
\hline
\end{tabular}

Source: Tilden (1957) 
The relevance of the basic principles of interpretation of this version of the research conducted by researchers is the content of the application. Interpretation of cultural heritage also includes various ways to communicate history and cultural heritage to tourists or visitors. This way of communicating either directly or known as live interpretation or through the media. Live interpretation is generally done by a guide or someone who is dressed or plays a character in a century / past. Whereas interpretations using media (slideshows, movie headsets, sound systems, music, mannequins), can generally be found in museums or historical sites (Howard 2003). A similar statement was stated by ICOMOS (2008) that the scope of communication of interpretations can be done through print and electronic media, public lectures, education programs, community activities, and research, training (ICOMOS 2008)

The link between the concept of Heritage interpretation and this research is to offer new media for interpreting cultural heritage through the Augmented Reality. Augmented Reality Applications have advantages over the existing guidance tools, which are generally only limited to sound in an outdoor area or photos and videos in an indoor. The Augmented Reality Application can be accessed in an open space with audio visuals. http://ojs.unud.ac.id/index.php/eot
Communicating the history of cultural heritage through Augmented Reality Will be very interactive because users can carry media anywhere that contains audio-visual content.

\section{METHODS}

This research has been at the stage of prototyping of the application. Therefore, in the first year the data collection method was focused on documentation, interview and making a prototype.

\section{Documentation Study}

This method was used in order to seek for old photos to be used as a database on the application. These old photos will be used as virtual data layering a real situation. This is in accordance with the concept of Augmented Reality. Searching for old photos is not merely limited to the world wide web or the internet, but also searches for old books, newspapers, magazines and all print media that allows researchers to find old photos located in Sanur, Kuta and Uluwatu. The first location that the researcher is the Bali Post Office on Jalan Kepundung number 67, because researchers believe that the Bali Post which was established in 1948 certainly has an old archive they have stored and contains photos of Bali in the 
past. But apparently, the Bali Post Office did not keep old newspapers published in the 1970s and 1980s, in their libraries only newspaper clippings were available in the early 2000s to date. It applies also to Nusa Daily, a competitor of Bali Post. Through a visit to the office in the two newspapers, the researcher gain the information that the regional archive and library office located in Renon, keeping archives of old Bali Post and Nusa newspapers from the early 1970 s to the 1980 s.

The search for these old photos even reach to Singapore, precisely at the Kinokuniya Bookstore, the most complete and largest bookstore in Southeast Asia. Finally the researchers asked for help from several friends who are studying in Europe, especially the Netherlands, to find books about Bali in the 1970s and 1980s. Researchers focused on the Lonely Planet travel guide book published in the $1070 \mathrm{~s}$ and 1980s

\section{Interview}

Some interviews were conducted in order to obtain the information about Kuta, Sanur and Uluwatu... From these interviews, information obtained is about the history of these places. The interviews were conducted with the aim of making a narrative which later included in prototype. Hence, when tourists use this http://ojs.unud.ac.id/index.php/eot application, tourists not merely see pictures or photos on the application however also listening to narrative stories about areas, this is where there is a collaboration between Digital Tourism and Tourism Heritage occurred.

\section{Observation}

One of the most common types of observation is usability study observation. Usability research involves users who try to use a prototype. This method in this era is widely used to understand how people work with mobile equipment such as mobile phones. The purpose of testing is directed at finding deficiencies that cause problems for users and the challenges they experience when using the mobile device. Recently, a number of writers have adopted and contributed to the development of usability testing methods for mobile devices (Oulasvirta, 2012; Kjeldskov and Skov, 2014). In line with the purpose of the research conducted, the study of the usefulness of mobile devices is felt appropriate, because it allows getting more data and information about problems that may be experienced by users of Reality.

e-ISSN: 2407-392X. p-ISSN: 2541-0857 
The application prototype produced

Making this application was time consuming because it was fairly complex. In the early stages of making this prototype there were many errors and also the inability of programmer to understand the researchers' ideas. The most obvious complexity is when determining the ordinate position of a tourist attraction where old photos appeared and layering the situation or real space. Then, the second problem that arises was the addition of the slider button. This button is very significant for this application prototype because through it, old photos can be made modified. The photos must be able to be displayed through the degree of transparency (translucent, transparent and opaque). Certainly, the foremost purpose of this application is be able to display a comparison between present and past condition of tourist attractions through the degree of transparency of old photos.

Figure 5 shows the opening page when this prototype is opened. A green circle logo represents a time tunnel. This logo had been through many changes since the researchers wanted to ensure the logo will attract potential users to download the application available on Android and IOS. The use of the Lempuyang temple at the beginning of the page is to represent
Heritage tourism and Balinese culture, Lempuyang is also known as one of the favourite tourist attractions in Bali.

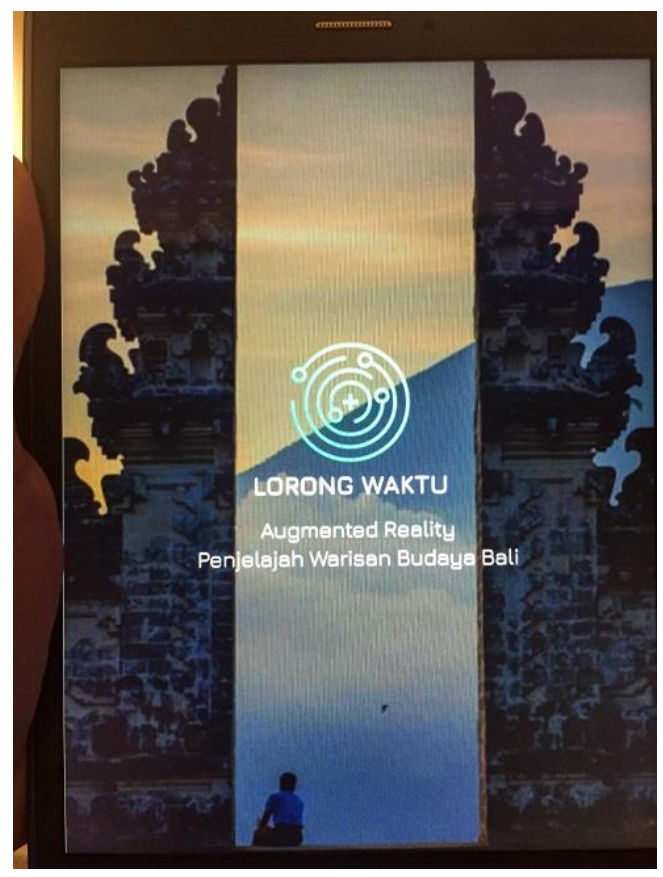

Figure 5: Opening page of Application Prototype

Source : Lorong Waktu app

Figure 6 shows about the information of this application where it can be seen offering a new experience of traveling in exploring cultural heritage in Bali. In this application is also informed to choose the desired menu and then directing the camera on mobile phone or tablets, thus information of Bali cultural heritage will be appeared according to the selected location. This information is available, both in photos and audios. 


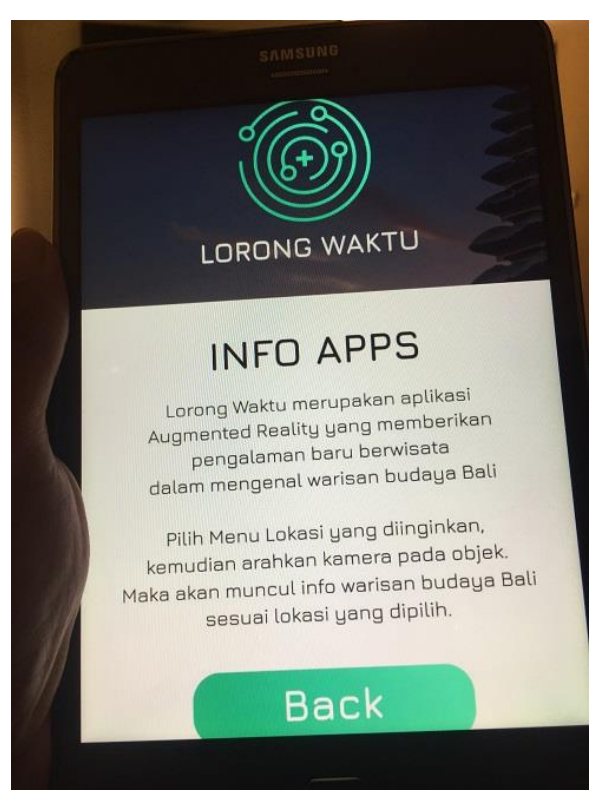

Figure 6: Information page of application prototype

Source : Lorong Waktu App

Figure 7 depicts the main menu of this application prototype. In this menu, there are three options such as play, info, exit. Firstly, Play tab displays location at three areas, namely Uluwatu, Sanur and Kuta. Then from there tourists can be directed to the desired tourist attractions, the old photos will appear along with the slider and audio in the form of narration. Secondly, the info menu explains about this application, the usage and finally, the exit menu is when user want to leaves the apps.

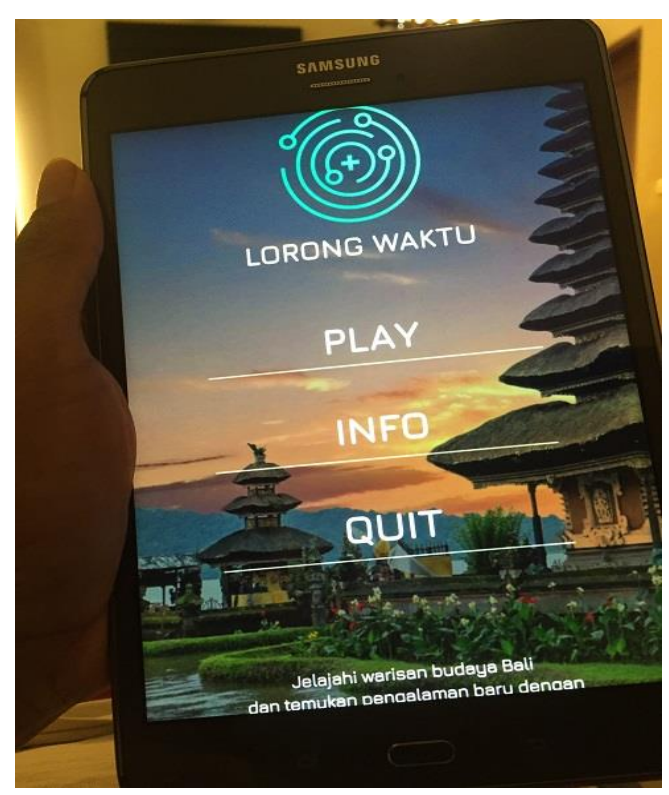

Figure 7: Main Menu of the Application Prototype

Source : Lorong Waktu App

This a three-year research will continue in the second year by compiling more old photo photos in Uluwatu, Sanur and Kuta area. In addition, the narrative is not solely available Indonesian language where only domestic tourists are targeted, however there will also be narratives in Mandarin and English. Mandarin narrative will be conducted by students from China who studies at Tourism Faculty of Udayana University. It is hoped that with Mandarin language option, there is an opportunity to promote this product to Chinese tourists who visit Bali. Narrative will also employ a narrator who has English as mother tongue. This will be attained by researchers from their Australian colleague or if it is not likely 
obtained it will be done through someone who is a mixed or descendant using English in everyday life. This is an extraordinary discovery and breakthrough since it is able to increase the selling power of cultural heritage-based tourism to tourists visiting Bali, both local and foreign tourists, in this case those who speak English and Mandarin.

\section{REFERENCES}

Abdullah, F., 2014. Analisa Media Pembelajaran Interaktif Berbasis Augmented Reality Studi Kasus Pengenalan Angka pada Anak TK Mekar Budi Demak. Skripsi, Fakultas Ilmu Komputer.

Adrianti, R., Sari, S.K. and Hidayat, W., 2016. Media Pembelajaran Cara Mudah Belajar Shalat Berbasis Augmented Reality Untuk Siswa Kelas Tiga Sekolah Dasar (studi Kasus Sd Ar-rafi'). eProceedings of Applied Science, 2 (3).

Anindya, M.B., Crisnapati, P.N., Sunarya, I.M.G. and Kesiman, M.W.A., 2014. Augmented Reality Book Pengenalan Tata Letak Bangunan Beserta Landscape Alam Pura Luhur Batukaru. Jurnal Nasional Pendidikan Teknik Informatika (JANAPATI), 3(3), pp.132-142.

Atmojo, Y.P. and Paramartha, I.G.N.D., 2014. Pemanfaatan Augmented Reality Pada Sistem Informasi Geografis Kampus Di Bali. Jurnal Sistem dan Informatika (JSI), 9(1), pp.63-74.

http://ojs.unud.ac.id/index.php/eot
Attila, K. and Edit, B., 2012, September. Beyond reality: The possibilities of augmented reality in cultural and heritage tourism. In 2nd International Tourism and Sport Management Conference, Debrecen (Vol. 5, No. 6).

Azuma, R., Baillot, Y., Behringer, R., Feiner, S., Julier, S. and MacIntyre, B., 2001. Recent advances in augmented reality. NAVAL RESEARCH LAB WASHINGTON DC.

Cahyani, A.A.H., Crisnapati, P.N., Sunarya, I.M.G. and Arthana, I.K.R., 2014. Augmented Reality Book Pengenalan Tata Letak Bangunan dan Landscape Alam Pura Lempuyang. Jurnal Nasional Pendidikan Teknik Informatika (JANAPATI), 3(3), pp.124-131.

Chang, Y.L., Hou, H.T., Pan, C.Y., Sung, Y.T. and Chang, K.E., 2015. Apply an augmented reality in a mobile guidance to increase sense of place for heritage places. Journal of Educational Technology \& Society, 18(2).

Chung, N., Han, H. and Joun, Y., 2015. Tourists' intention to visit a destination: The role of augmented reality (AR) application for a heritage site. Computers in Human Behavior, 50, pp.588-599.

Darmawiguna, I.G.M., Kesiman, M.W.A., Crisnapati, P.N., Wiartika, I.M.E., Suparianta, K.D., Susena, I.K. and Yudiantara, I.M., 2014. Augmented reality for the documentation of cultural heritage building modelling in Bali, Indonesia. In Kultur un Informatik: Reality and Virtuality, Proceeding of Culture and Computer Science Conference, Berlin, Germany (pp. 107-117). 
Dharmawan, A.B. and Lubis, C., 2017. Perancangan Website Promosi Parawisata Indonesia Dengan Aplikasi Augmented Reality. SEMNASTEKNOMEDIA ONLINE, 5(1), pp.4-7.

Feiner, S., MacIntyre, B., Höllerer, T. and Webster, A., 1997. A touring machine: Prototyping 3D mobile augmented reality systems for exploring the urban environment. Personal

Technologies, 1(4), pp.208-217.

Fuad, E., Nugraha, A. and Khoiril, M., 2017. Penerapan Augmented Reality Sebagai Media Informasi Kadar Nutrisi Buah Durian Melalui Objek Kemasan Produk. Jurnal Dinamika Informatika, 6(2), pp.1730.

Girbacia, F., Butnariu, S., Orman, A.P. and Postelnicu, C.C., 2013. Virtual restoration of deteriorated religious heritage objects using augmented reality technologies. European Journal of Science and Theology, 9(2), pp.223-231.

Gonydjaja, R. and Pratomo, A., 2016. Aplikasi Penjualan Rumah Pada Perumahan Prima Harapan Rgency Bekasi Berbasis Augmented Reality MEnggunakan Artoolkit. UG Journal, 9(5).

Gretzel, U., Werthner, H., Koo, C. and Lamsfus, C., 2015. Conceptual foundations for understanding smart tourism ecosystems. Computers in Human Behavior, 50, pp.558-563.

Han, D.I., Jung, T. and Gibson, A., 2013. Dublin AR: implementing augmented reality in tourism. In Information and communication technologies in tourism 2014 (pp. 511-523). Springer, Cham.

Henrysson, A. and Ollila, M., 2004, October. UMAR: Ubiquitous mobile augmented reality. In Proceedings of the 3rd international conference on Mobile and ubiquitous multimedia (pp. 4145). ACM.

Hidayat, T., 2015. Aplikasi Mobile Android untuk Pemasaran Perumahan Menggunakan Metode Markerless Augmented Reality pada PT. Alifa Citra Mulia. SATIN-Sains dan Teknologi Informasi, 1(1), pp.47-54.

Howard, P., 2003. Heritage: management, interpretation, identity. $\mathrm{A} \& \mathrm{C}$ Black.

Huda, N. and Purwaningtias, F., 2017. Perancangan Aplikasi Pembelajaran Pengenalan Huruf Dan Angka Berbasis Augmented Reality. Jurnal Sisfokom (Sistem Informasi dan Komputer), 6(2), pp.116-120.

ICOMOS, A., 2008. The ICOMOS Charter for the Interpretation and Presentation of Cultural Heritage Sites.

Johan, V.A. and Syarif, A.C., 2015. Penerapan Augmented Reality Sebagai Media Pembelajaran Budaya Rumah Adat Sulawesi Selatan. TEMATIKA, Journal of Informatics and Information Systems, 3(1), pp.15-22.

Jung, T.H. and Han, D.I., 2014. Augmented Reality (AR) in Urban Heritage Tourism.e-Review of Tourism Research, 5.

Jung, T., Chung, N. and Leue, M.C., 2015. The determinants of recommendations to use augmented reality technologies: The case of a Korean theme park. Tourism management, 49, pp.75-86.

e-ISSN: 2407-392X. p-ISSN: 2541-0857 
Kamelia, L., 2015. Perkembangan Teknologi Augmented Reality Sebagai Media Pembelajaran Interaktif Pada Mata Kuliah Kimia Dasar. Jurnal Istek, 9(1).

Khotimah, K. and Ardian, Y., 2017. Aplikasi Media Pembelajaran Ilmu Pengetahuan Alam (IPA) dengan Teknologi Augmented Reality (Studi Kasus: Kelas IV SDN Sukun 2 Malang). Jurnal Mahasiswa Fakultas Sains dan Teknologi, 1(5).

Kjeldskov, J. and Skov, M.B., 2014, September. Was it worth the hassle?: ten years of mobile HCI research discussions on lab and field evaluations. In Proceedings of the 16th international conference on Human-computer interaction with mobile devices \& services (pp. 43-52). Acm.

Kounavis, C. D., Kasimati, A. E., Zamani, E. D., \& Giaglis, G. M. 2012. Enhancing the tourism experience through mobile augmented reality: Challenges and prospects. International Journal of Engineering Business Management, 4(10), 1-6.

Langlotz, T., Nguyen, T., Schmalstieg, D. and Grasset, R., 2014. Nextgeneration augmented reality browsers: rich, seamless, and adaptive. Proceedings of the IEEE, 102(2), pp.155-169.

Lengkey, D.M., Rindengan, Y.D. and Tulenan, V., 2014. Brosur Fakultas Teknik Universitas Sam Ratulangi Manado Dengan Teknologi Markerless Augmented Reality. EJOURNAL TEKNIK ELEKTRO DAN KOMPUTER, 3(4), pp.1-10.
Lubis, S.S., Wijaya, H.W., Sidiq, Z.I. and Pudjoatmodjo, B., 2016. Game Petualangan Mengangkat Kisah Rama Dan Rahwana Menggunakan Teknologi Kinect. eProceedings of Applied Science, 2(2).

Madden, L., 2011. Professional augmented reality browsers for smartphones: programming for junaio, layar and wikitude. John Wiley \& Sons.

Milgram, P., Takemura, H., Utsumi, A., \& Kishino, F. (1994). Augmented reality: A class of displays on the reality-virtuality continuum. In Proceedings of the Telemanipulator and Telepresence Technologies, Boston, MA

Mohring, M., Lessig, C. and Bimber, O., 2004, November. Video seethrough AR on consumer cellphones. In Proceedings of the 3rd IEEE/ACM International Symposium on Mixed and Augmented Reality (pp. 252-253). IEEE Computer Society.

Muhammad, S., 2014. Implementasi Display Produk Furniture Berbasis Mobile Menggunakan Augmented Reality (Doctoral dissertation, Universitas Widyatama).

Neuhofer, B., Buhalis, D. and Ladkin, A., 2013. Experiences, co-creation and technology: A conceptual approach to enhance tourism experiences. CAUTHE 2013: Tourism and Global Change: On the Edge of Something Big, p.562.

Novitasari, D. and Arianto, F., 2017. Pengembangan Augmented Reality Berbasis Android Materi Sistem Pernapasan Manusia Untuk Siswa Kelas xi IPA di SMA Negeri 1 Porong. Jurnal Mahasiswa Teknologi Pendidikan, 1(3). 
Novitasari, A.D. and Hernawan Sulistyanto, S.T., 2017. Perancangan Sistem Informasi Tempat Ibadah Beragam Agama Di Kota Solo (Doctoral dissertation, Universitas Muhammadiyah Surakarta)

Oulasvirta, A., 2012. Rethinking experimental designs for field evaluations. IEEE Pervasive Computing, 11(4), pp.60-67.

Prabowo, A.Z., Satoto, K.I. and Martono, K.T., 2015. Perancangan dan Implementasi Augmented Reality sebagai Media Promosi Penjualan Perumahan. Jurnal Teknologi dan Sistem Komputer, 3(1), pp.161170.

Pratama, A.S. and Anwar, K., 2013. Aplikasi Penunjuk Arah Lokasi Kampus Stimata Menggunakan Teknologi Augmented Reality. JURNAL TEKNOLOGI INFORMASI: Teori, Konsep, dan Implementasi, 4(2), pp.75-89.

Putra, D.T., 2013. Rancang Bangun Buku Eensiklopedia Dinosaurus dengan Teknologi Augmented Reality (AR) Berbasis Multimedia Sebagai Media Pembelajaran (Doctoral dissertation, UNIVERSITAS ISLAM NEGERI SULTAN SYARIEF KASIM RIAU).

Rachman, Y., 2013. Augmented Reality Kantor Pos Jakarta Timur Dalam Bentuk Location Based Services Menggunakan Platform Layar Pada Smartphone Android.

Saputra, D.I.S., Utami, E. and Sunyoto, A., 2015, July. Penerapan Mobile Augmented Reality Berbasis Cloud Computing Pada Harian Umum Radar Banyumas. In Seminar Nasional Informatika (SEMNASIF) (Vol. 1, No. 2).
Saputro, R.E. and Saputra, D.I.S., 2015. Pengembangan Media Pembelajaran Mengenal Organ Pencernaan Manusia Menggunakan Teknologi Augmented Reality. Jurnal Buana Informatika, 6(2).

Senduk, E.P. and Karouw, S., 2016. MLearning Pendidikan Karakter untuk Anak Usia Dini Berbasis Augmented Reality. Jurnal Teknik Informatika Universitas Sam Ratulangi, 9(1).

Seo, B.K., Kim, K., Park, J. and Park, J.I., 2010, December. A tracking framework for augmented reality tours on cultural heritage sites. In Proceedings of the 9th ACM SIGGRAPH Conference on Virtual-Reality Continuum and its Applications in Industry (pp. 169174). ACM.

Setiawan, A. and Haryanto, H., 2012. Aplikasi Pendeteksi Tanggal Kadaluarsa Makanan Tradisional Kota Semarang dengan Augmented Reality. Semantik, 2(1).

Setiawan, A., Haryanto, H. and Wijayanti, S., 2013. Aplikasi Augmented Reality Sebagai Promosi Bangunan Bersejarah Di Kota Semarang. Jurnal Teknik Informatika. Universitas Dian Nuswantoro Semarang.

Setyawan, R.A. and Dzikri, A., 2016. Analisis Penggunaan Metode Marker Tracking Pada Augmented Reality Alat Musik Tradisional Jawa Tengah. Simetris: Jurnal Teknik Mesin, Elektro dan Ilmu Komputer, 7(1), pp.295-304.

Stricker, D., Pagani, A. and Zoellner, M., 2010. In-situ visualization for cultural heritage sites using novel augmented reality technologies. Virtual Archaeology Review, 1(2), pp.37-41. 
Tahyudin, I. and Saputra, D.I.S., 2017, November. Aplikasi Augmented Reality (AR) Sebagai Inovasi Promosi Objek Wisata di Kabupaten Purbalingga. In Seminar Nasional Informatika (SNIf) (Vol. 1, No. 1, pp. 660-665).

Tambayong, M.O., Lumenta, A.S. and Sugiarso, B.A., 2016. Implementasi Augmented Reality Pada Sistem Sirkulasi Darah Manusia. Jurnal Teknik Elektro dan Komputer, 5(3), pp.49-57.

Tilden, F., 1957. Interpreting our heritage: Principles and practices for visitor services in parks, museums, and historic places. University of North Carolina Press.

Triyanti, Y.D. and Marleen, O., 2014. Aplikasi Android Untuk Pencarian Lokasi Tempat Ibadah Di Wilayah Bekasi. Prosiding KOMMIT.

Yovcheva, Z., Buhalis, D. and Gatzidis, C., 2013. Engineering augmented tourism experiences. In Information and communication technologies in tourism 2013 (pp. 24-35). Springer, Berlin, Heidelberg.

Yudiantika, A.R., Sulistyo, S. and Hantono, B.S., 2015, June. The development of mobile augmented reality quiz visualization methods based on markerless tracking for museum learning application. In Disampaikan pada seminar "The International Forum on Strategic Technology (IFOST).

Zaini, T.M. and Endah, O.D., 2015. Promosi Objek Wisata Unggulan Lampung Melalui Media "Magicbook" Berteknologi Augmented Reality. Prosiding Sembistek 2014, 1(02), pp.674-685. 